\title{
Mikania mikrantha leaf extract mediated biogenic synthesis of magnetic iron oxide nanoparticles: Characterization and its antimicrobial activity study
}

\author{
Aayushi Biswas, ${ }^{a}$ C. Vanlalveni, ${ }^{b}$ R. Lalfakzuala, ${ }^{b}$ Soumitra Nath, ${ }^{c}$ Lalthazuala \\ Rokhum*a \\ aDepartment of Chemistry, National Institute of Technology Silchar, Silchar 788010, Assam, India. \\ bDepartment of Botany, Mizoram University, Tanhril, Aizawl, Mizoram, 796001, India \\ cDepartment of Biotechnology, Gurucharan College, Silchar 788001, Assam, India \\ *Corresponding authors e-mail addresses: rokhum@che.nits.ac.in; lalthazualarokhum@gmail.com; Tel.: +91 3842 242915; Fax: +91 3842 - \\ 224797
}

\begin{abstract}
With an aim to introduce a new highly potent antimicrobial nanoparticles using an environment-friendly route, he present work reports the green synthesis of iron oxide nanoparticles $\left(\mathrm{Fe}_{3} \mathrm{O}_{4} \mathrm{NPs}\right)$ utilizing Mikania mikrantha leaf extract and its application as efficient antimicrobial agent. The green $\mathrm{Fe}_{3} \mathrm{O}_{4} \mathrm{NPs}$ have been described by X-beam diffraction (XRD), Ultraviolet-Visible (UV-Vis) spectroscopy, Scanning Electron Microscopy (SEM), Transmission Electron Microscopy (TEM) and Fourier Transform-Infra Red (FT-IR) investigation. The TEM image shows the rhomboidal $\mathrm{Fe}_{3} \mathrm{O}_{4} \mathrm{NPs}$ with average mean sizes $20.27 \mathrm{~nm}$. The FT-IR investigation proved $\mathrm{Fe}_{3} \mathrm{O}_{4} \mathrm{NPs}$ have been balanced out through the associations of steroids, terpenoids, flavonoids, phenyl propanoids, phenolic acids and proteins present in the leaf extract. The synthesized $\mathrm{Fe}_{3} \mathrm{O}_{4} \mathrm{NPs}$ shows a very high antibacterial and antifungal property against 5 bacterial strains such as Bacillus cereus, Acinetobacter johnsonii, Pseudomonas aeruginosa, Achromobacter spanius and Chromobacterium pseudoviolaceum strain, and 4 fungal strains (Aspergillus niger, Penicillium citirinum, Fusarium oxysporium, and Candida albicans). The green synthesized iron oxide nanoparticles can interfere metabolic activities of microorganisms which determine its antimicrobial properties and could bring a promising application in the fields of medicine.
\end{abstract}

Keywords: Biosynthesis, $\mathrm{Fe}_{3} \mathrm{O}_{4}$ nanoparticles, Mikania mikrantha, Characterization, Antimicrobial activity.

\section{Introduction}

Nanoparticles synthesized from metal or metal-oxides are the trending study of plant engineering and nanotechnology [1],[2].The diverse and most imperative characteristics of the nanoparticles synthesized from metal/metal-oxide nanoparticles is that they discloses superior activity [3],[4].The bio-nanoparticles have lots of uses and application in the field of medical diagnostic [5], bio-engineering [6], drug-delivery [7],[8], antimicrobial [9],[10], larvisidal, catalyst for chemical reactions, and electronics-devices. Due to the global sensible use of nanoparticles $(<100 \mathrm{~nm})$ has ascribable for varieties in distinctive qualities. Nanoparticles biosynthesized are widely synthesized using chemical-synthesis method or physical-synthesis techniques, which uses one to prepare the particles with the common characteristics many ways like, heating, electrolytic study, sedimentation precipitation, wet chemical reaction, deposition, and sonicating the nanoparticles are being used for bio- synthesize of nanoparticles [11],[12],[13],[14]. Still these synthesis methods, are typically favourable and labour-intensive and are probably some projects using to the environmental and ecofriendly techniques using plants, fungi algae etc. were carried out. Green synthesis has advances over chemical and physical method because it is price operative, atmosphere friendly, vital structural plenty of engineering.

Metal nanoparticles are widely synthesized victimization physical and chemical processes, which allow one to accumulate particles with the popular characteristics, many ways like hydrothermal, conventional heating , anodization, deposition precipitation, wet chemical reaction, deposit, and sonication area unit being applied to synthesize the nanoparticles. However, these production methods are typically high-priced and effortful, hence green synthesis of nanoparticles has gain momentum these days [15],[16],[17]. Green synthesis has advances over chemical and physical method because it is value operative, atmosphere friendly, and easily [18],[19]. With the 
recent speedy development and evolvement of technology, personalities have placed their religion in nanotechnology and believe that it will ameliorate their current living commonplace [20],[21]. As a consequence, the nanoparticle has drawn a large interest from researchers globally thanks to specific characteristics such as form, size, and distribution, that can be utilized in an exceedingly distinct field of applications [22],[23]. Synthesis of $\mathrm{Fe}_{3} \mathrm{O}_{4} \mathrm{NPs}$ has been dispensed because of its unique properties, like being super paramagnetic, biocompatible, perishable, and expected to be non-toxic to humans [24],[25]. These distinctive properties allow $\mathrm{Fe}_{3} \mathrm{O}_{4} \mathrm{NPs}$ to be wide employed in totally different areas of applications, like chemical process, magnetic storage media [26], biosensors [27], resonance imaging (MRI) [28],[29], and targeted drug delivery [30],[31],[32]. Numerous strategies of fabrication of $\mathrm{Fe}_{3} \mathrm{O}_{4} \mathrm{NPs}$ will be used, like sol gel technique, solid state synthesis and flame spray synthesis [33]. In distinction to the long chemical and physical strategies which involve sophisticated procedures, inexperienced technique is much easier and safer to use, and plant-mediated synthesis of nanoparticles remains a replacement theme and therefore the outcome is however to be studied.

With the recent speedy development and evolvement of technology, personalities have placed their religion in nanotechnology and believe that it will ameliorate their current living commonplace. As a consequence, the nanoparticles has drawn a large interest from researchers globally thanks to specific characteristics such as form, size, and distribution, that can be utilized in an exceedingly distinct field of applications [34],[35]. Synthesis of $\mathrm{Fe}_{3} \mathrm{O}_{4} \mathrm{NPs}$ has been dispensed as a result of its unique properties, like being super paramagnetic, biocompatible, perishable, and expected to be non-toxic to humans [36]. These distinctive properties allow $\mathrm{Fe}_{3} \mathrm{O}_{4} \mathrm{NPs}$ to be wide employed in totally different areas of applications, like chemical process, magnetic storage media, biosensors, resonance imaging (MRI), and targeted drug delivery [37]. Numerous strategies of fabrication of $\mathrm{Fe}_{3} \mathrm{O}_{4} \mathrm{NPs}$ will be used, like sol gel technique, solid state synthesis and flame spray synthesis. In distinction to the long chemical and physical strategies which involve sophisticated procedures, inexperienced technique is much easier and safer to use, and plant-mediated synthesis of nanoparticles remains a replacement theme and therefore the outcome is however to be studied. There are a few of successful studies in synthesizing $\mathrm{Fe}_{3} \mathrm{O}_{4} \mathrm{NPs}$ by plant extract. as an example, fruit extract of Psidium guajava [38], leaf extract of genus Perilla frutescens [36],[29], Tridax procumbens [39] and Caricaya papaya [28], peel extract of plantain [40],[41], and additionally seed extract of grape proanthocyanidin [42]. Here, in continuation to our interest in the green synthesis of nanoparticles such as silver nanoparticles using Mikania mikrantha leaf extract for its antimicrobial activities [43], we reported the use of Mikania mikrantha leaf extract as a reducing and stabilizing agent for the green synthesis of iron oxide nanoparticles. The $\mathrm{Fe}_{3} \mathrm{O}_{4} \mathrm{NPs}$ obtained were fully characterized by Fourier transform infrared (FT-IR), transmission electron microscopy (TEM), energy dispersive X-ray spectroscopy (EDS) and X-ray diffraction (XRD), Scanning electron microscope (SEM) and Vibrating sample magnetometer (VSM). The as-synthesized $\mathrm{Fe}_{3} \mathrm{O}_{4} \mathrm{NPs}$ were studied to observe its efficacy as antimicrobial agents.

\section{Experimental}

A brief description of all the used reagents, chemicals, experimental procedure, and various analysis data obtained by different spectroscopic methods are covered under this section.
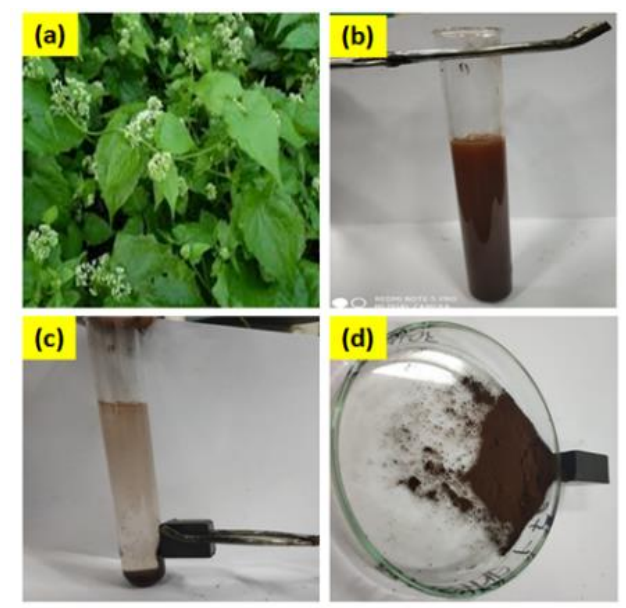

FIGURE 1: a) Mikania mikrantha plant with leaves, b) Reaction mixture, c) Magnetic property of the precipitate $\mathrm{Fe}_{3} \mathrm{O}_{4}$ nanoparticles in the reaction mixture, d) washed and dried magnetic $\mathrm{Fe}_{3} \mathrm{O}_{4}$ nanoparticles 


\subsection{Materials}

Ferrous sulphate $\left(\mathrm{FeSO}_{4} .7 \mathrm{H}_{2} \mathrm{O}\right)$, Ferric chloride $\left(\mathrm{FeCl}_{3}\right)$, were purchased from Sigma-Aldrich. Double distilled deionized water was used for carrying out the whole experiment. Mikania mikrantha leaves for the experiment were collected from NIT Silchar campus (Silchar, Assam, India).

\subsection{Preparation of Mikania mikrantha leaf extract}

Fresh leaves of Mikania mikrantha plants were collected, washed thoroughly 3-4 times with double distilled water to remove external impurities, dust particles and finally chopped to fine pieces. $40 \mathrm{~g}$ of the finely chopped Mikania mikrantha leaf were boiled in $100 \mathrm{~mL}$ of double distilled water at $90{ }^{\circ} \mathrm{C}$ for $20 \mathrm{~min}$. The solution of the Mikania mikrantha leaf extract was then cooled to room temperature and filtered using filter paper of Whatman No. 41 grade and was stored at $-4{ }^{\circ} \mathrm{C}$ for future experimental purpose.

\subsubsection{Synthesis of magnetic iron oxide nanoparticles}

5 mmol of $\mathrm{FeSO}_{4} \cdot 7 \mathrm{H}_{2} \mathrm{O}$ and $10 \mathrm{mmol}$ of $\mathrm{FeCl}_{3}\left(\mathrm{Fe}^{2+}: \mathrm{Fe}^{3+}=1: 2\right.$ molar ratio) were dissolved in $100 \mathrm{~mL}$ of distilled water at $80{ }^{\circ} \mathrm{C}$. $25 \mathrm{~mL} \mathrm{M}$. mikrantha leaf extract was then added drop by drop to the reaction mixture with continuous stirring. The reaction solution slowly changes its color from colorless to dark brown. The reaction mixture was then allowed to settle to form the precipitate. The formed $\mathrm{Fe}_{3} \mathrm{O}_{4} \mathrm{NPs}$ was easily separated by using an external magnet. The $\mathrm{Fe}_{3} \mathrm{O}_{4} \mathrm{NPs}$ precipitate moved towards the magnet and sticks to the wall of the test-tube hence justifying its magnetic property (Fig. 1).

\subsubsection{Screening of Antimicrobial Property of synthesized $\mathrm{Fe}_{3} \mathrm{O}_{4} \mathrm{NPs}$.}

Test microorganisms:

In vitro antimicrobial screening includes 5 bacterial and 4 fungal strains. The bacterial strains includes Bacillus cereus strain SN_SA, Acinetobacter johnsonii strain SB_SK, Pseudomonas aeruginosa strain SN1, Achromobacter spanius strain GCCSB1 and Chromobacterium pseudoviolaceum strain GCC-SO4, having NCBI-GenBank accession number MH482928, MH482927, KF031122, MK000623 and MH109305 respectively. The laboratory fungal isolates include Aspergillus niger, Penicillium citirinum, Fusarium oxysporium, Candida albicans. Bacterial strains were grown and maintained on nutrient agar medium, while fungi were maintained on potato dextrose agar (PDA) medium.

\section{Results and Discussion}

In this chapter, we have discussed the biosynthesis of an inexpensive, $\mathrm{Fe}_{3} \mathrm{O}_{4} \mathrm{NPs}$ using Mikania mikrantha. Furthermore, the synthesized $\mathrm{Fe}_{3} \mathrm{O}_{4} \mathrm{NPs}$ was characterized by various analytical and spectroscopic techniques.

\subsection{FT-IR analysis}

The FT-IR spectroscopic studies were carried out to investigate interaction between the surface of $\mathrm{Fe}_{3} \mathrm{O}_{4} \mathrm{NPs}_{\mathrm{s}}$ and the organic functional groups of the biomolecules present in the M. mikrantha plant leaf extract. The FT-IR spectrum of aqueous extract of M. mikrantha was shown in Fig. 2. The absorption bands at $3302 \mathrm{~cm}^{-1}$ and $3317 \mathrm{~cm}^{-1}$ are due to are because of the extending vibrations of $\mathrm{O}-\mathrm{H}$ bunch in alcohols and phenolic mixes and extending vibrations of $\mathrm{N}$ $\mathrm{H}$ in auxiliary amides. The groups at 1641 and $1636 \mathrm{~cm}^{-1}$ are normal for amide I and amide II groups, individually. Appearance of two small new peaks at 585 and $626 \mathrm{~cm}^{-1}$ is the characteristic absorbance peak of $\mathrm{Fe}_{3} \mathrm{O}_{4}$ confirming the formation of $\mathrm{Fe}_{3} \mathrm{O}_{4} \mathrm{NPs}$ from plant source [44]. 


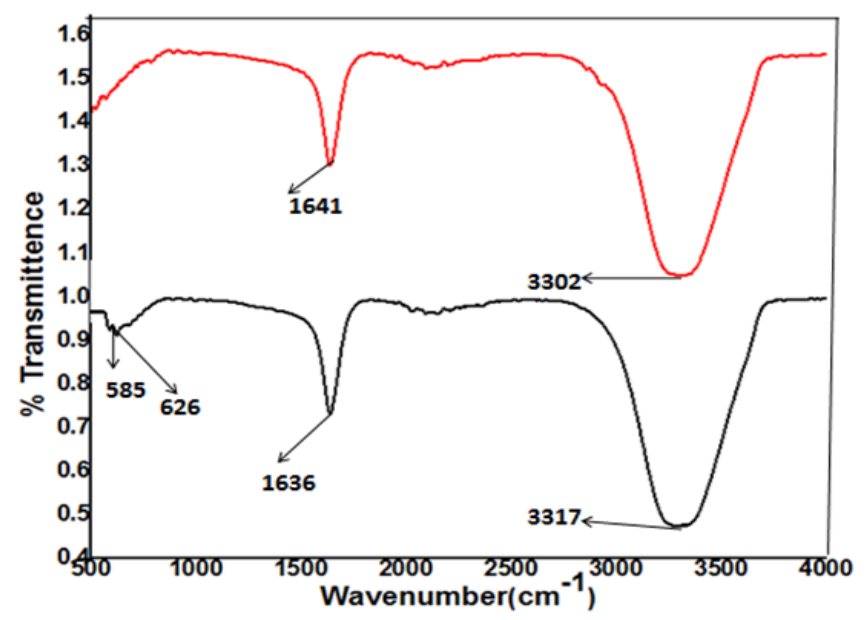

FIGURE 2: FT-IR of Mikania mikrantha $\mathrm{Fe}_{3} \mathrm{O}_{4}$ nanoparticles

3.2 XRD analysis

The phase composition and nature of the biosynthesized $\mathrm{Fe}_{3} \mathrm{O}_{4} \mathrm{NPs}$ from Mikania mikrantha leaf extract was analyzed by XRD analysis (Fig. 3) with intense Bragg's angle ranging from 100 to 800 and was found that the XRD peaks values are $30.27,35.60,36.75,43.41,53.88,57.38$ and 62.90 corresponding to (220), (311), (222), (400), (422), (511) and (440) proving the crystalline form of the nanoparticle with (JCPDS: 75-1610). The average crystallite size is $20.27 \mathrm{~nm}$ which is calculated by Debye-Scherer's formula.

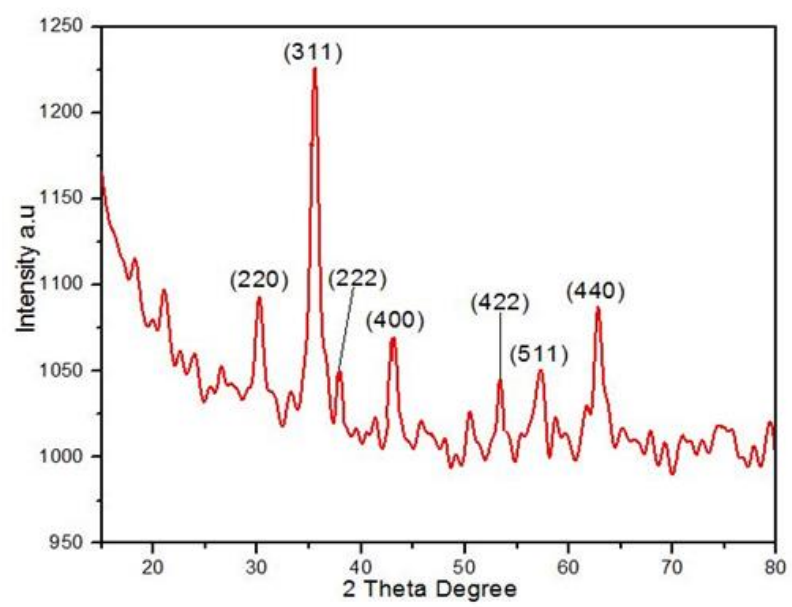

FIGURE 3: XRD pattern of Mikania mikrantha $\mathrm{Fe}_{3} \mathrm{O}_{4}$ nanoparticles

\subsection{TEM, SAED analysis}

The TEM analysis elucidates morphology and size of the synthesized resultant $\mathrm{Fe}_{3} \mathrm{O}_{4} \mathrm{NPs}$. In Figure 4, the TEM images at various magnifications (a-d) and selected area electron diffraction (SAED) patterns (e) and nanoparticles size distribution graph are shown [45]. From the TEM images of synthesized $\mathrm{Fe}_{3} \mathrm{O}_{4} \mathrm{NPs}$ we have seen poly-dispersed and the majority of them being rhomboidal in shape with particle size ranged from 15 to $20 \mathrm{~nm}$ and a mean of 20.27 $\mathrm{nm}$. SAED pattern confirms the crystalline nature of the NPs. The nanoparticles distribution curve shows that majority of them are in the range of $20 \mathrm{~nm}$. The $\mathrm{Fe}_{3} \mathrm{O}_{4} \mathrm{NPs}$ were seen surrounded by thin layer, which is predicted to be the capping agents, organic compounds from the Mikania mikrantha leaf extract. 

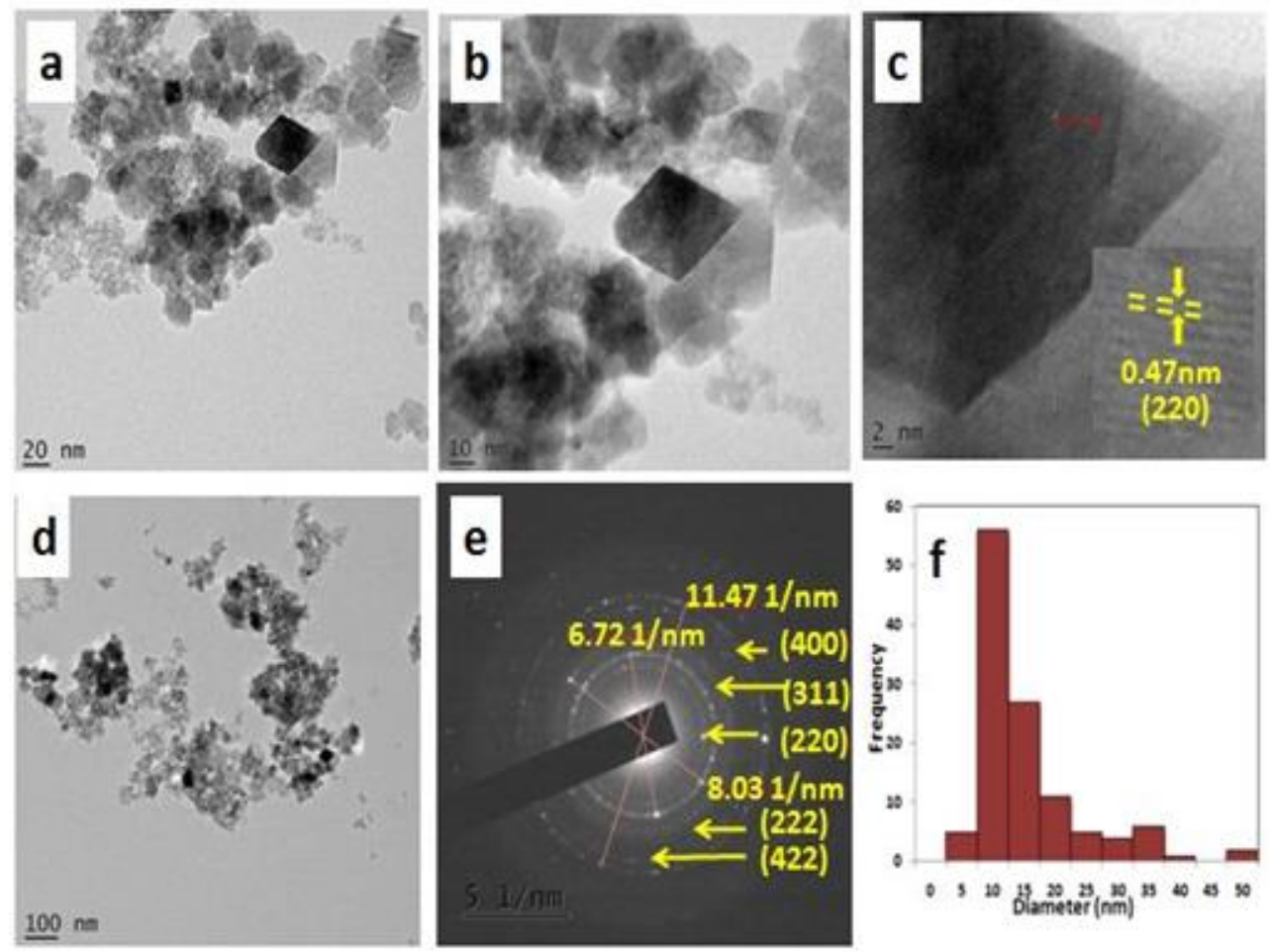

FIGURE 4: TEM images (a-d), SAED pattern (e) and size distribution graph of $\mathrm{Fe}_{3} \mathrm{O}_{4}$ nanoparticles

\subsection{SEM and EDX analysis}

SEM image confirmed the rhomboidal shape, well dispersed nature of the nanoparticles with average 15-20 nm sized nanoparticles and a mean size of 20.27. To have more insight of the chemical composition and further information of the metallic nature of the synthesized nanoparticles we have studied the EDX [46]. In this study generally the interaction takes place between X-rays and the compound to be investigated results in reflection of the peak of metal or compounds present in the sample. The obtained peak amplitude shows the presence of particular elements in the compound. Iron generally depicts amplitude peak at $0.7-7 \mathrm{keV}$. From our EDS analysis we can see the presence compounds showing peaks at 0.4, 6.5 and 7.0 respectively. Elemental compositions percentage of the synthesized $\mathrm{Fe}_{3} \mathrm{O}_{4} \mathrm{NPs}$ from Mikania mikrantha leaf extract were also calculated (Figure 5).
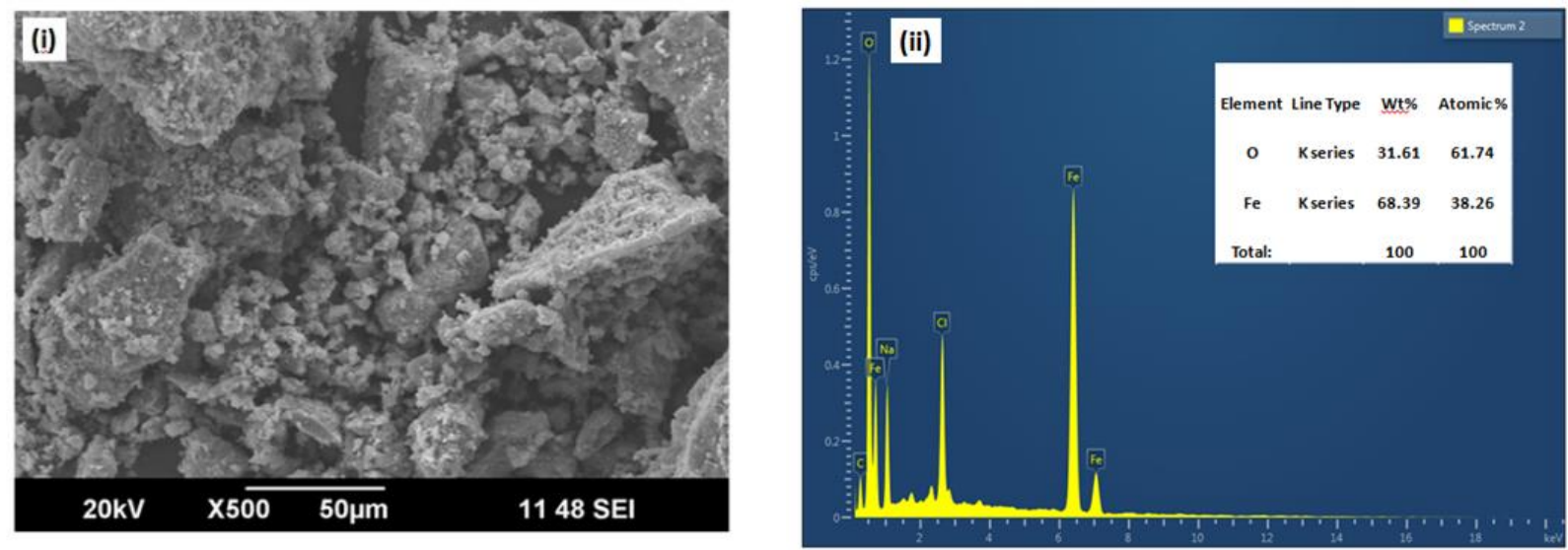

FIGURE 5 (i) SEM (ii) EDS pattern of Mikania mikrantha $\mathrm{Fe}_{3} \mathrm{O}_{4}$ nanoparticles 


\section{$3.5 \mathrm{VSM}$ analysis}

The vibrating sample magnetometer (VSM) is carried out for checking the magnetic properties of biosynthesized $\mathrm{Fe}_{3} \mathrm{O}_{4}$ nanoparticles from M. mikrantha leaf extracts. The super paramagnetic property and magnetic nature of $\mathrm{Fe}_{3} \mathrm{O}_{4}$ nanoparticles magnetization measurement is also recorded with VSM (Fig.6). The magnetization curve displays zero remanence and co-ercivity, with a specific high magnetization saturation at $60.50 \mathrm{emu} / \mathrm{g}$ respectively which stipulates the super paramagnetic properties of the biosynthesized $\mathrm{Fe}_{3} \mathrm{O}_{4}$ nanoparticles, which closely matched with the reported literature [47]. Due to its super paramagnetism, the biosynthesized $\mathrm{Fe}_{3} \mathrm{O}_{4}$ nanoparticles solution responds to the magnets when bought closer an applied magnetic field despite of having any fixed magnetization and disperse back very fast as soon as the magnet is being removed [48]. Hence the biosynthesized $\mathrm{Fe}_{3} \mathrm{O}_{4}$ nanoparticles from Mikania mikrantha leaf extract may have varied applications in, biological, antimicrobial and biomedical studies because of its high super paramagnetic property and easy recoverability using an external magnet.

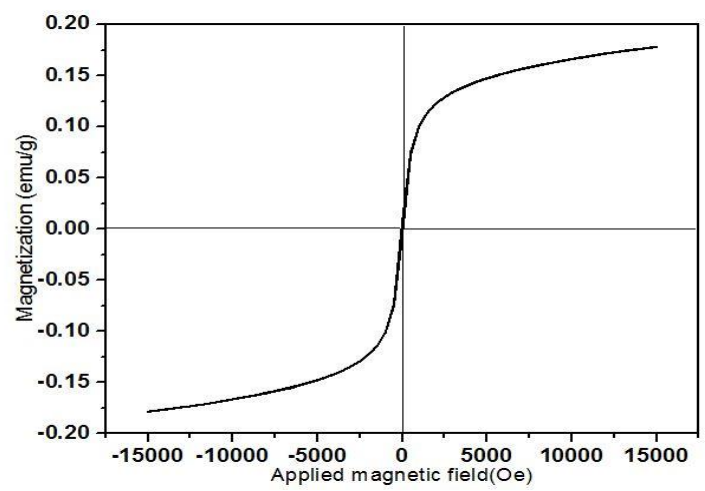

FIGURE 6: VSM pattern of Mikania mikrantha mediated $\mathrm{Fe}_{3} \mathrm{O}_{4} \mathrm{NPs}$

\subsection{Antimicrobial activity}

Antimicrobial activity was performed by agar well diffusion method, with slight modifications. Freshly prepared molten Muller Hinton Agar (MHA) media for bacterial culture and Potato Dextrose Agar (PDA) media for fungal culture were poured to uniform depth of $5 \mathrm{~mm}$ and allowed to cool at room temperature [49],[43],[50]. After solidification, wells were made in MHA media by $6 \mathrm{~mm}$ sterilized cork borer. 1-2 drops of media poured in the bottom with the help of sterile micropipette. $1-2 \times 107 \mathrm{cfu} / \mathrm{mL}$ of test microorganisms were spread onto the surface of MHA media using a glass spreader. $50 \mu 1$ of $\mathrm{Fe}_{3} \mathrm{O}_{4} \mathrm{NPs}$ of three different concentrations $(1.0 \mathrm{mM}, 0.5 \mathrm{mM}$ and 0.25 $\mathrm{mM}$ ) were then filled in three wells. DMSO was also used as negative control. The plates were then incubated for 24 $\mathrm{h}$ at $37{ }^{\circ} \mathrm{C}$ for bacterial culture and $48 \mathrm{~h}$ at $25^{\circ} \mathrm{C}$ for fungal culture. The antibacterial activity of $\mathrm{Fe}_{3} \mathrm{O}_{4} \mathrm{NPs}$ was evaluated by measuring the zone of inhibition (ZOI) in millimeter with a very high antibacterial activity as shown in Figure 7 and Table 1 and was found that Bacillus cereus strain SN_SA shows the highest ZOI of $13 \mathrm{~mm}$ at $1.0 \mathrm{mM}$, $10 \mathrm{~mm}$ at $0.5 \mathrm{mM}$ and $8 \mathrm{~mm}$ at $0.25 \mathrm{mM}$, followed by Acinetobacter johnsonii strain SB_SK $13 \mathrm{~mm}$ at $1.0 \mathrm{mM}, 10$ $\mathrm{mm}$ at $0.5 \mathrm{mM}$ and $6 \mathrm{~mm}$ at $0.25 \mathrm{mM}$, Chromobacterium pseudoviolaceum strain GCC-SO4showing $13 \mathrm{~mm}$ at 1.0 $\mathrm{mM}, 6 \mathrm{~mm}$ at $0.5 \mathrm{mM}$, and $5 \mathrm{~mm}$ at $0.25 \mathrm{mM}$, Pseudomonas aeruginosa strain $\mathrm{SN} 1$ showing $10 \mathrm{~mm}$ at $1.0 \mathrm{mM}, 5$ $\mathrm{mm}$ at $0.5 \mathrm{mM}$, and $0 \mathrm{~mm}$ at $0.25 \mathrm{mM}$ and Achromobacter spanius strain GCCSB1 showing the least among the five bacterial strains with $9 \mathrm{~mm}$ at $1.0 \mathrm{mM}, 7 \mathrm{~mm}$ at $0.5 \mathrm{mM}$, and $6 \mathrm{~mm}$ at $0.25 \mathrm{mM}$.

Table 1. Antibacterial activity of measurement of $\mathrm{ZOI}$ at three concentrations of $\mathrm{Fe}_{3} \mathrm{O}_{4}$ nanoparticles against five pathogenic bacteria a) Bacillus cereus b) Acinetobacter johnsonii strain SB_SK c) Pseudomonas aeruginosa d) Achromobacter spanius strain GCCSB1 e Chromobacterium pseudoviolaceum strain GCC-SO4) (i) $0.25 \mathrm{mM}$ (ii) $0.5 \mathrm{mM}$ (iii) $1 \mathrm{mM}$

\begin{tabular}{lllll}
\hline Test microorganisms & Test sample & Test sample & Test sample & Control \\
Bacterial isolates & $1.0 \mathrm{mM}$ & $0.5 \mathrm{mM}$ & $0.25 \mathrm{mM}$ & 0 \\
\hline 1. Bacillus cereus strain SN_SA & 13 & 10 & 8 & 0 \\
\hline
\end{tabular}




\begin{tabular}{lllll}
\hline 2. Acinetobacter johnsonii strain SB_SK & 13 & 10 & 6 & 0 \\
3. Pseudomonas aeruginosa strain SN1 & 10 & 5 & 0 & 0 \\
4. Achromobacter spanius strain GCCSB1 & 9 & 7 & 6 & 0 \\
5.Chromobacterium pseudoviolaceum strain GCC- & 13 & 6 & 5 & 0 \\
SO4 & & & \\
\hline
\end{tabular}
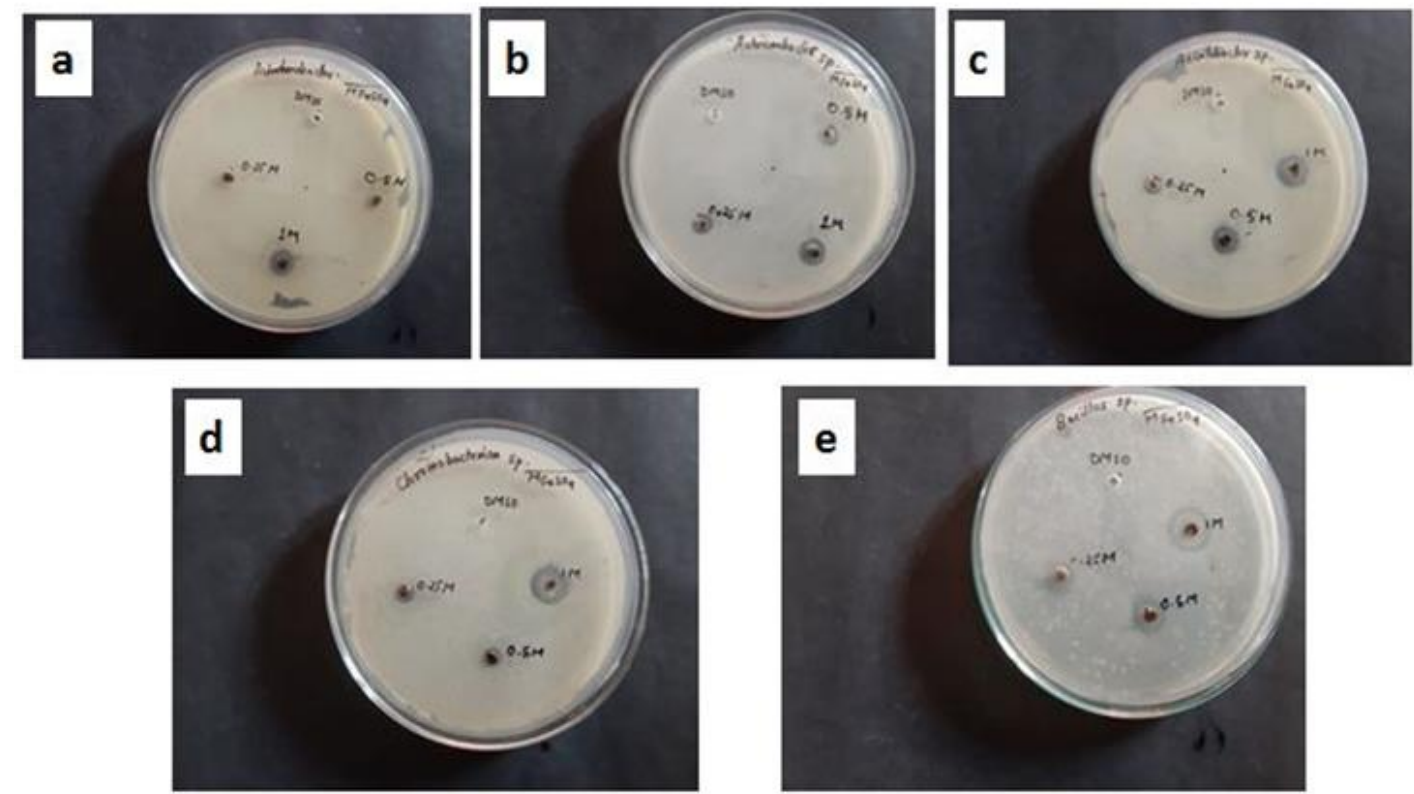

FIGURE 7: Antibacterial activity, ZOI caused by biosynthesized Mikania mikrantha $\mathrm{Fe}_{3} \mathrm{O}_{4}$ nanoparticles against five pathogenic bacteria. a) Bacillus cereus b) Acinetobacter johnsonii strain SB_SK c) Pseudomonas aeruginosa d) Achromobacter spanius strain GCCSB1e Chromobacterium pseudoviolaceum strain GCC-SO4)

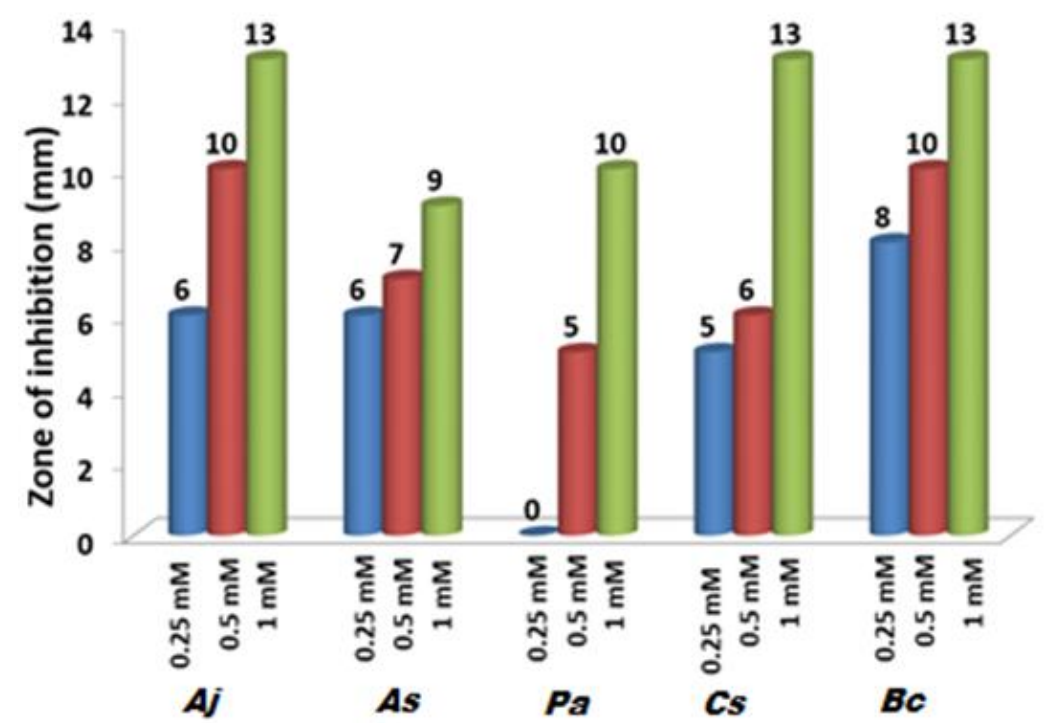


FIGURE 8: Bar chart of Antibacterial activity, ZOI caused by biosynthesized Mikania mikrantha $\mathrm{Fe}_{3} \mathrm{O}_{4}$ nanoparticles against five pathogenic bacteria a) Bacillus cereus b) Acinetobacter johnsonii strain SB_SK c) Pseudomonas aeruginosa d) Achromobacter spanius strain GCCSB1 e) Chromobacterium pseudoviolaceum strain GCC-SO4) at concentration (i) $0.25 \mathrm{mM}$ (ii) $0.5 \mathrm{mM}$ (iii) $1 \mathrm{mM}$

The antifungal activity of $\mathrm{Fe}_{3} \mathrm{O}_{4} \mathrm{NPs}$ was also evaluated by measuring the ZOI in millimeter with also very high antifungal activity as shown in Figure 9 and Table 2 and was found that among the four fugal strain studied for antifungal activity the Candida albicans showing the highest ZOI $20 \mathrm{~mm}$ at $1.0 \mathrm{mM}, 19 \mathrm{~mm}$ at $0.5 \mathrm{mM}$, and $14 \mathrm{~mm}$ at $0.25 \mathrm{mM}$, followed by Penicillium citirinum, showing $14 \mathrm{~mm}$ at $1.0 \mathrm{mM}, 13 \mathrm{~mm}$ at $0.5 \mathrm{mM}$, and $10 \mathrm{~mm}$ at 0.25 $\mathrm{mM}$, Aspergillus niger showing $10 \mathrm{~mm}$ at $1.0 \mathrm{mM}, 8 \mathrm{~mm}$ at $0.5 \mathrm{mM}$, and $6 \mathrm{~mm}$ at $0.25 \mathrm{mM}$, and Fusarium oxysporium showing the least antifungal activity $10 \mathrm{~mm}$ at $1.0 \mathrm{mM}, 7 \mathrm{~mm}$ at $0.5 \mathrm{mM}$, and $0 \mathrm{~mm}$ at $0.25 \mathrm{mM}$ respectively.

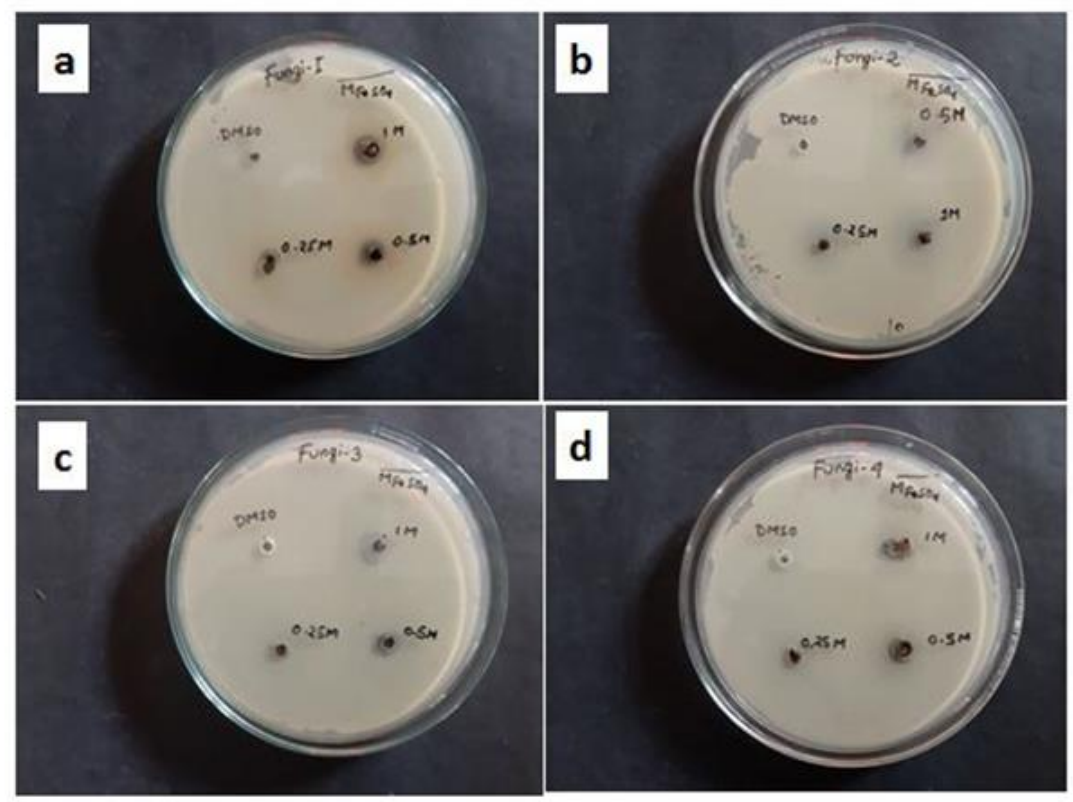

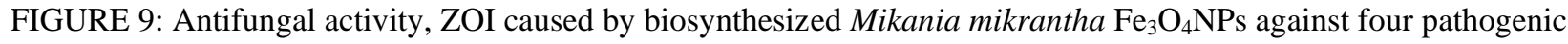
fungi a) Aspergillus niger b) Penicillium citirinum c) Fusarium oxysporium d) Candida albicans (i) $0.25 \mathrm{mM}$ (ii) 0.5 $\mathrm{mM}$ (iii) $1 \mathrm{mM}$ 


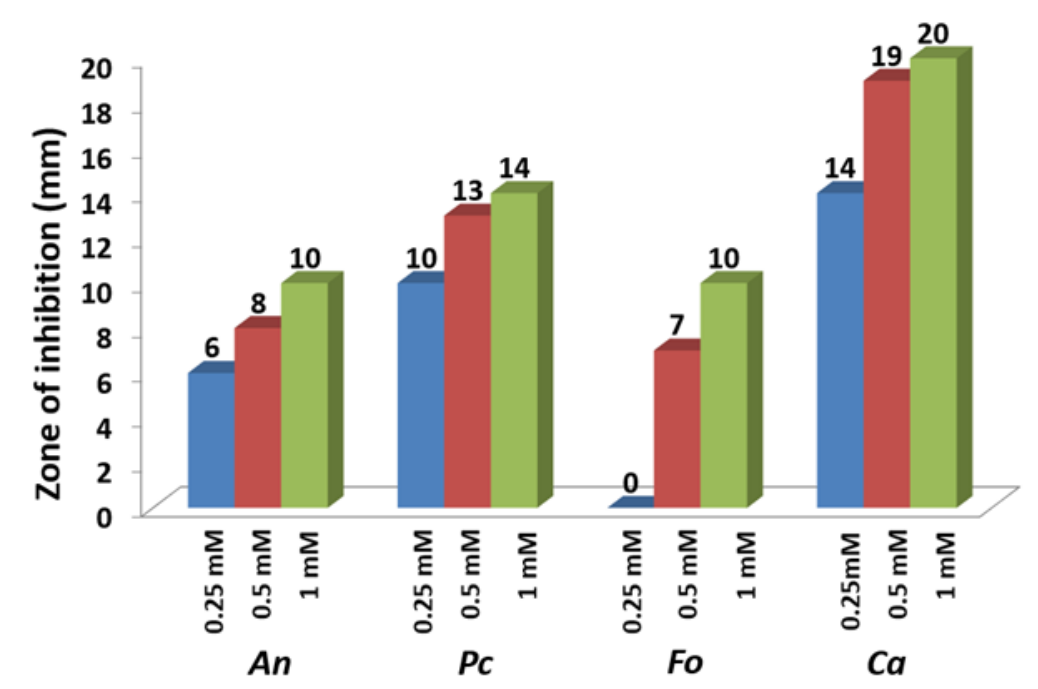

FIGURE 10: Bar chart of antifungal activity ZOI caused by biosynthesized Mikania mikrantha $\mathrm{Fe}_{3} \mathrm{O}_{4}$ nanoparticles against four pathogenic fungi a) Aspergillus niger b) Penicillium citirinum c) Fusarium oxysporium d) Candida albicans at concentration (i) $0.25 \mathrm{mM}$ (ii) $0.5 \mathrm{mM}$ (iii) $1.0 \mathrm{mM}$

Table 2 Antifungal activity of measurement of $\mathrm{ZOI}$ at three concentrations of $\mathrm{Fe}_{3} \mathrm{O}_{4}$ nanoparticles against four pathogenic fungi a) Aspergillus niger b) Penicillium citirinum c) Fusarium oxysporium d) Candida albicans (i) $0.25 \mathrm{mM}$ (ii) $0.5 \mathrm{mM}$ (iii) $1 \mathrm{mM}$

\begin{tabular}{lllll}
\hline Test microorganisms & Test sample & Test sample & Test sample & Control \\
Fungal isolates & $1.0 \mathrm{mM}$ & $0.5 \mathrm{mM}$ & $0.25 \mathrm{mM}$ & 0 \\
\hline 1. Aspergillus niger & 10 & 8 & 6 & 0 \\
2. Penicillium citrium & 14 & 13 & 10 & 0 \\
3. Fusarium oxysporium & 10 & 7 & 0 & 0 \\
4. Candida albicans & 20 & 19 & 14 & 0 \\
\hline
\end{tabular}

\section{Conclusions}

In summary, magnetic iron oxide nanoparticles were successfully synthesized using Mikania mikrantha leaf extract by heating at a temperature of $90{ }^{\circ} \mathrm{C}$. The impacts of strengthening temperature on molecule size and auxiliary properties of nanoparticles were monitored utilizing FT-IR, XRD, SEM, TEM and VSM analysis. The FTIR indicated a wide retention band identified with $\mathrm{Fe}_{3} \mathrm{O}_{4}$ vibration band. The XRD examination affirmed that the forerunner was $\mathrm{Fe}_{3} \mathrm{O}_{4}$ and the combined $\mathrm{Fe}_{3} \mathrm{O}_{4}$ nanoparticles have rhomboidal structure. The XRD and TEM investigation demonstrated that the normal molecule size of $\mathrm{Fe}_{3} \mathrm{O}_{4}$ particles increments with expanding strengthening temperatures. Furthermore, the SEM results demonstrated the arrangement of well dispersed rhomboidal formed nanoparticles. From the TEM examination, the normal molecule sizes of the $\mathrm{Fe}_{3} \mathrm{O}_{4} \mathrm{NPs}$ were 15$20 \mathrm{~nm}$ respectively with a mean size of $20.27 \mathrm{~nm}$. Due to the increasing number of microbes resistant to antibiotic drugs available in the market, a new molecule with high inhibiting efficacy towards microbes is in great demand. Hence, several NPs have been investigated in this line. Interestingly our newly synthesized $\mathrm{Fe}_{3} \mathrm{O}_{4} \mathrm{NPs}$ shows a very high antibacterial and antifungal property against 5 bacterial strains and 4 fungal strains with maximum activity against Bacillus cereus strain SN_SA and Candida albicans strains hence proving its efficacy in biological application as antimicrobial agents. Owing to its high antibacterial and antifungal property, our newly introduced $\mathrm{Fe}_{3} \mathrm{O}_{4} \mathrm{NPs}$ will be a good addition to the existing antimicrobial drugs available in the market.

\section{Acknowledgment}

We thankfully acknowledge SERB, New Delhi for research fund (grant nos. SB/FT/CS-103/2013 and SB/EMEQ076/2014). 


\section{References}

[1] S. Ahmad, S. Munir, N. Zeb, A. Ullah, B. Khan, J. Ali, M. Bilal, M. Omer, M. Alamzeb, S.M. Salmanm, S. Ali, Green nanotechnology: A review on green synthesis of silver nanoparticles-An ecofriendly approach. Int. J. Nanomed. 14 (2019) 5087-5107

[2] D. Sharma, S. Kanchi, K. Bisetty, Biogenic synthesis of nanoparticles: a review. Arab J Chem 12 (2019) 3576-3600.

[3] V. V. Makarov, A.J. Love, O. V. Sinitsyna, S.S. Makarova, I. V. Yaminsky, M.E. Taliansky, N.O. Kalinina, "Green" nanotechnologies: Synthesis of metal nanoparticles using plants, Acta Naturae. 6 (2014) 35-44.

[4] S. Sarkar, E. Guibal, F. Quignard, A.K. SenGupta, Polymer-supported metals and metal oxide nanoparticles: Synthesis, characterization, and applications, J. Nanoparticle Res. (2012).

[5] A.B. Seabra, N. Durán, Nanotoxicology of metal oxide nanoparticles, Metals (Basel). (2015).

[6] S.K. Liao, W.Q. Cai, W.Y. Liu, L. Zhang, Y. Li, J.G. Ren, J. Yin, Q. Shen, Y. Cao, Z.P. Li, F.Z. Li, X.W. Chen, L.H. Sun, J.J. Jia, J.C. Wu, X.J. Jiang, J.F. Wang, Y.M. Huang, Q. Wang, Y.L. Zhou, L. Deng, T. Xi, L. Ma, T. Hu, Q. Zhang, Y.A. Chen, N. Le Liu, X. Bin Wang, Z.C. Zhu, C.Y. Lu, R. Shu, C.Z. Peng, J.Y. Wang, J.W. Pan, Satellite-to-ground quantum key distribution, Nature. (2017).

[7] P. Jamdagni, P. Khatri, J.S. Rana, Green synthesis of zinc oxide nanoparticles using flower extract of Nyctanthes arbor-tristis and their antifungal activity, J. King Saud Univ. - Sci. (2018).

[8] Y.P. Yew, K. Shameli, M. Miyake, N.B.B.A. Khairudin, S.E.B. Mohamad, T. Naiki, K.X. Lee, Green biosynthesis of superparamagnetic magnetite $\mathrm{Fe} 3 \mathrm{O} 4$ nanoparticles and biomedical applications in targeted anticancer drug delivery system: A review. Arab. J. Chem. (2018), 1-22

[9] A.M. Muthukrishnan, Green Synthesis of Copper-Chitosan Nanoparticles and Study of its Antibacterial Activity, J. Nanomed. Nanotechnol. (2015).

[10] D. Garibo, HA. Borbón-Nuñez, JND. de León, E.G Mendoza, I. Estrada, Y. Toledano-Magaña, H. Tiznado , M. Ovalle-Marroquin, AG. Soto-Ramos, A. Blanco, JA. Rodríguez, OA. Romo, LA. Chávez-Almazán, A. Susarrey-Arce, Green synthesis of silver nanoparticles using Lysiloma acapulcensis exhibit highantimicrobial activity. Sci Rep 10 (2020) 12805.

[11] S. Jain, M.S. Mehata, Medicinal Plant Leaf Extract and Pure Flavonoid Mediated Green Synthesis of Silver Nanoparticles and their Enhanced Antibacterial Property, Sci. Rep. (2017).

[12] P.C. Nagajyothi, T.V.M. Sreekanth, Green synthesis of metallic and metal oxide nanoparticles and their antibacterial activities, in: Green Process. Nanotechnol. From Inorg. to Bioinspired Nanomater., 2015.

[13] A.C. Dhanemozhi, V. Rajeswari, S. Sathyajothi, Green Synthesis of Zinc Oxide Nanoparticle Using Green Tea Leaf Extract for Supercapacitor Application, in: Mater. Today Proc., 2017.

[14] R.K. Ameta, K.R. Shankar, M. Singh, Plant Extract: An Effective Medium for Synthesis of Metal Nanoparticles, SF J. Nanochemistry Nanotechnol. (2018).

[15] S. Jebril, R. Khanfir Ben Jenana, C. Dridi, Green synthesis of silver nanoparticles using Melia azedarach leaf extract and their antifungal activities: In vitro and in vivo. Mater. Chem. Phys. 248 (2020), 122898.

[16] G. Gahlawat, A.R. Choudhury, A review on the biosynthesis of metal and metal salt nanoparticles by microbes, RSC Adv. (2019).

[17] C. Vanlalveni, K. Rajkumari, A. Biswas, P.P. Adhikari, R. Lalfakzuala, L. Rokhum, Green Synthesis of Silver Nanoparticles Using Nostoc linckia and its Antimicrobial Activity: a Novel Biological Approach, Bionanoscience. 8 (2018) 624-631.

[18] S.A. Dahoumane, E.K. Wujcik, C. Jeffryes, Noble metal, oxide and chalcogenide-based nanomaterials from scalable phototrophic culture systems, Enzyme Microb. Technol. (2016).

[19] M.S. Alnarabiji, N. Yahya, Y. Hamed, S.E.M. Ardakani, K.A. Mohd Azizi, J.J. Klemeš, B. Abdullah, S.F.H. Tasfy, S.B.A. Hamid, O. Nashed, Scalable bio-friendly method for production of homogeneous metal oxide nanoparticles using green bovine skin gelatin, J. Clean. Prod. (2017).

[20] M. Nadeem, D. Tungmunnithum, C. Hano, B.H. Abbasi, S.S. Hashmi, W. Ahmad, A. Zahir, The current trends in the green syntheses of titanium oxide nanoparticles and their applications, Green Chem. Lett. Rev.

[21] J. Jeevanandam, Y.S. Chan, M.K. Danquah, Biosynthesis and characterization of MgO nanoparticles from plant extracts via induced molecular nucleation, New J. Chem. (2017).

[22] D. Suresh, R.M. Shobharani, P.C. Nethravathi, M.A. Pavan Kumar, H. Nagabhushana, S.C. Sharma, Artocarpus gomezianus aided green synthesis of $\mathrm{ZnO}$ nanoparticles: Luminescence, photocatalytic and antioxidant properties, Spectrochim. Acta - Part A Mol. Biomol. Spectrosc. 141 (2015) 128-134.

[23] S. Azizi, M.B. Ahmad, F. Namvar, R. Mohamad, Green biosynthesis and characterization of zinc oxide nanoparticles using brown marine macroalga Sargassum muticum aqueous extract, Mater. Lett. 116 (2014) 
275-277.

[24] Y. Yi, G. Tu, P.E. Tsang, S. Xiao, Z. Fang, Green synthesis of iron-based nanoparticles from extracts of Nephrolepis auriculata and applications for Cr(VI) removal, Mater. Lett. 234 (2019) 388-391.

[25] P. Lakshmi Pravallika, G. Krishna Mohan, K. Venkateswara Rao, K. Shanker, Biosynthesis, characterization and acute oral toxicity studies of synthesized iron oxide nanoparticles using ethanolic extract of Centella asiatica plant, Mater. Lett. 236 (2019) 256-259.

[26] C.P. Devatha, A.K. Thalla, S.Y. Katte, Green synthesis of iron nanoparticles using different leaf extracts for treatment of domestic waste water, J. Clean. Prod. 139 (2016) 1425-1435.

[27] L. Huang, X. Weng, Z. Chen, M. Megharaj, R. Naidu, Synthesis of iron-based nanoparticles using oolong tea extract for the degradation of malachite green, Spectrochim. Acta - Part A Mol. Biomol. Spectrosc. 117 (2014) 801-804.

[28] D. Aksu Demirezen, Y.Ş. Yıldız, Ş. Yılmaz, D. Demirezen Yılmaz, Green synthesis and characterization of iron oxide nanoparticles using Ficus carica (common fig) dried fruit extract, J. Biosci. Bioeng. 127 (2019) 241-245.

[29] Z. Izadiyan, K. Shameli, M. Miyake, H. Hara, S.E.B. Mohamad, K. Kalantari, S.H.M. Taib, E. Rasouli, Cytotoxicity assay of plant-mediated synthesized iron oxide nanoparticles using Juglans regia green husk extract, Arab. J. Chem. (2018).

[30] S. Venkateswarlu, B.N. Kumar, B. Prathima, Y. SubbaRao, N.V.V. Jyothi, A novel green synthesis of Fe 3 O 4 magnetic nanorods using Punica Granatum rind extract and its application for removal of $\mathrm{Pb}$ (II) from aqueous environment, Arab. J. Chem. 12 (2019) 588-596.

[31] C.A. De León-Condés, G. Roa-Morales, G. Martínez-Barrera, P. Balderas-Hernández, C. MenchacaCampos, F. Ureña-Núñez, A novel sulfonated waste polystyrene / iron oxide nanoparticles composite: Green synthesis, characterization and applications, J. Environ. Chem. Eng. 7 (2019) 102841.

[32] S. Amutha, S. Sridhar, Green synthesis of magnetic iron oxide nanoparticle using leaves of Glycosmis mauritiana and their antibacterial activity against human pathogens, J. Innov. Pharm. Biol. Sci. 5 (2015) 2226.

[33] L. Huang, X. Weng, Z. Chen, M. Megharaj, R. Naidu, Green synthesis of iron nanoparticles by various tea extracts: Comparative study of the reactivity, Spectrochim. Acta - Part A Mol. Biomol. Spectrosc. 130 (2014) 295-301.

[34] M. Mahdavi, F. Namvar, M. Bin Ahmad, R. Mohamad, Green biosynthesis and characterization of magnetic iron oxide (Fe 3O4) nanoparticles using seaweed (Sargassum muticum) aqueous extract, Molecules. 18 (2013) 5954-5964.

[35] F. Namvar, H.S. Rahman, R. Mohamad, J. Baharara, M. Mahdavi, E. Amini, M.S. Chartrand, S.K. Yeap, Cytotoxic effect of magnetic iron oxide nanoparticles synthesized via seaweed aqueous extract, Int. J. Nanomedicine. 9 (2014) 2479-2488.

[36] Y.P. Yew, K. Shameli, M. Miyake, N. Kuwano, N.B. Bt Ahmad Khairudin, S.E. Bt Mohamad, K.X. Lee, Green Synthesis of Magnetite (Fe3O4) Nanoparticles Using Seaweed (Kappaphycus alvarezii) Extract, Nanoscale Res. Lett. 11 (2016).

[37] G.M. Sulaiman, A.T. Tawfeeq, A.S. Naji, Biosynthesis, characterization of magnetic iron oxide nanoparticles and evaluations of the cytotoxicity and DNA damage of human breast carcinoma cell lines, Artif. Cells, Nanomedicine Biotechnol. 46 (2018) 1215-1229.

[38] K.M. Ponvel, F. Mercy, Biosynthesis of iron oxide nanoparticles using Psidium guajava fruit extract, Int. J. Recent Res. Asp. (2018) 727-730.

[39] A.B. Patil, C.S. Panse, S.K. Mengane, Biosynthesis of silver nano particles from Tridax procumbens and its antioxidant potential: A novel biological approach, J. Bionanoscience. (2017).

[40] S. Venkateswarlu, Y.S. Rao, T. Balaji, B. Prathima, N.V.V. Jyothi, Biogenic synthesis of Fe3O4 magnetic nanoparticles using plantain peel extract, Mater. Lett. 100 (2013) 241-244.

[41] T. Wang, J. Lin, Z. Chen, M. Megharaj, R. Naidu, Green synthesized iron nanoparticles by green tea and eucalyptus leaves extracts used for removal of nitrate in aqueous solution, J. Clean. Prod. 83 (2014) 413419.

[42] V. V. Makarov, S.S. Makarova, A.J. Love, O. V. Sinitsyna, A.O. Dudnik, I. V. Yaminsky, M.E. Taliansky, N.O. Kalinina, Biosynthesis of stable iron oxide nanoparticles in aqueous extracts of Hordeum vulgare and rumex acetosa plants, Langmuir. 30 (2014) 5982-5988.

[43] A. Biswas, C. Vanlalveni, P.P. Adhikari, R. Lalfakzuala, L. Rokhum, Biosynthesis, characterisation and antibacterial activity of Mikania micrantha leaf extract-mediated AgNPs, Micro Nano Lett. (2019).

[44] T. Naseem, M.A. Farrukh, Antibacterial activity of green synthesis of iron nanoparticles using Lawsonia 
inermis and gardenia jasminoides leaves extract, J. Chem. 2015 (2015).

[45] S. Ahmadian-Fard-Fini, M. Salavati-Niasari, D. Ghanbari, Hydrothermal green synthesis of magnetic $\mathrm{Fe} 3 \mathrm{O} 4$-carbon dots by lemon and grape fruit extracts and as a photoluminescence sensor for detecting of $\mathrm{E}$. coli bacteria Spectrochim Acta Mol Biomol Spectrosc, 203 (2018), 481-493

[46] P. Cheera, S. Karlapudi, G. Sellola, V. Ponneri, A facile green synthesis of spherical Fe 3 O 4 magnetic nanoparticles and their effect on degradation of methylene blue in aqueous solution J. Mol. Liq., 221 (2016), 993-998

[47] R. Rahmani, M. Gharanfoli, M. Gholamin, M. Darroudi, J. Chamani, K. Sadri Green synthesis of 99mTclabeled- $\mathrm{Fe}_{3} \mathrm{O}^{4}$ nanoparticles using Quince seeds extract and evaluation of their cytotoxicity and biodistribution in rats J. Mol. Struct., 1196 (2019), 394-402

[48] Y. Cai, Y. Shen, A. Xie, S. Li, X. Wang, Green synthesis of soya bean sprouts-mediated superparamagnetic Fe $3 \mathrm{O} 4$ nanoparticles, J. Magn. Magn. Mater. 322 (2010) 2938-2943.

[49] A. Biswas, C. Vanlalveni, P.P. Adhikari, R. Lalfakzuala, L. Rokhum, Green biosynthesis, characterisation and antimicrobial activities of silver nanoparticles using fruit extract of Solanum viarum, IET Nanobiotechnology. (2018).

[50] A. Biswas, L. Chawngthu, C. Vanlalveni, R. Hnamte, R. Lalfakzuala, L. Rokhum, Biosynthesis of silver nanoparticles using Selaginella bryopteris plant extracts and studies of their antimicrobial and photocatalytic activities, J. Bionanoscience. (2018). 